\title{
Deep Venous Thrombosis and Klippel-Trénaunay Syndrome
}

\author{
Trombose Venosa Profunda e Síndrome de Klipper-Trénaunay
}

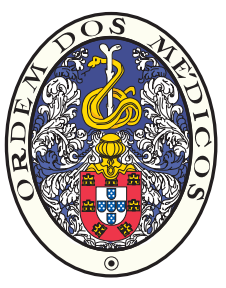

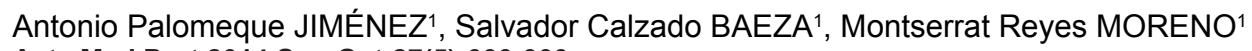
Acta Med Port 2014 Sep-Oct;27(5):666-666

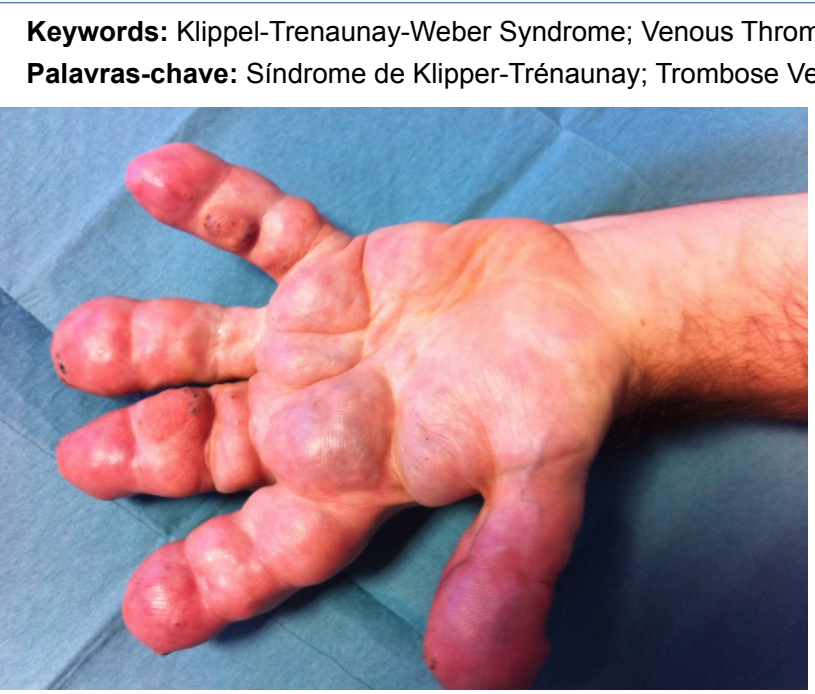

Figure 1 - Left hand with deep vein thrombosis

A 27 year old male with a history of Klippel-Trénaunay syndrome, who consults for pain and swelling in his left arm. On examination, there was an aberrant member enlargement and varicose veins, localized only at the forearm and left hand. (Fig.s 1,2). Coagulation: D-dimer $3.58 \mathrm{mg} / \mathrm{L}$. Doppler ultrasound showed thrombosis of the distal end of the left brachial vein and main branches dependent. He was treated with bandage on his arm, low molecular weight heparin and acenocoumarol for six months with resolution of symptoms.

The Klippel-Trénaunay syndrome is a rare congenital

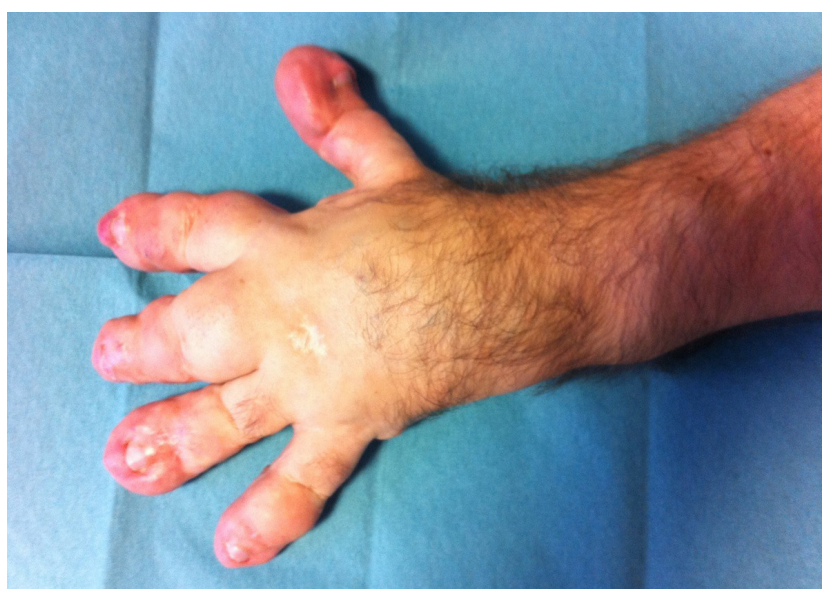

Figure 2 - Left hand with deep vein thrombosis

malformation. It is characterized by the triad of capillary malformations, atypical varicosities and hypertrophy of soft tissue and/or bone. ${ }^{1}$ The etiology is unknown and affects mainly to lower extremities. Exclusive afectation of the upper extremities is unusual, ${ }^{2}$ as occurred in the case described. There are systemic complications (coagulopathy, heart failure) and outlets such as deep vein thrombosis., ${ }^{2,3}$ The elevation of D-dimer and Doppler ultrasound are the mainstay of diagnosis. Treatment of venous thrombosis is immobilization, heparin and oral anticoagulants. ${ }^{3}$

\section{REFERENCES}

1. Moreno RV, Martinez P, Palazón R, Gil S. Síndrome de Klippel-Trénaunay: a propósito de un caso. Rehabilitacion. 2004;38:188-91.

2. Skourtis G, Lazoura O, Panoussis P, Livieratos L. Klippel-Trenaunay syndrome: an unusual cause of pulmonary embolism. Int Angiol. 2006;25:322-6.

3. Oduber CE, Van Beers EJ, Bresser P, Van der Horst CM, Meijers JC, Gerdes VE. Venous thromboemboism and prothrombotic parameters in KlippelTrenaunay syndrome. Neth J Med. 2013;71:246-52. 


\section{Deep Venous Thrombosis and Klippel-Trénaunay Syndrome}

Acta Med Port 2014:27:666-666

Publicado pela Acta Médica Portuguesa, a Revista Científica da Ordem dos Médicos

Av. Almirante Gago Coutinho, 151

1749-084 Lisboa, Portugal.

Tel: +351218428215

E-mail: submissao@actamedicaportuguesa.com

www.actamedicaportuguesa.com

ISSN:0870-399X | e-ISSN: 1646-0758

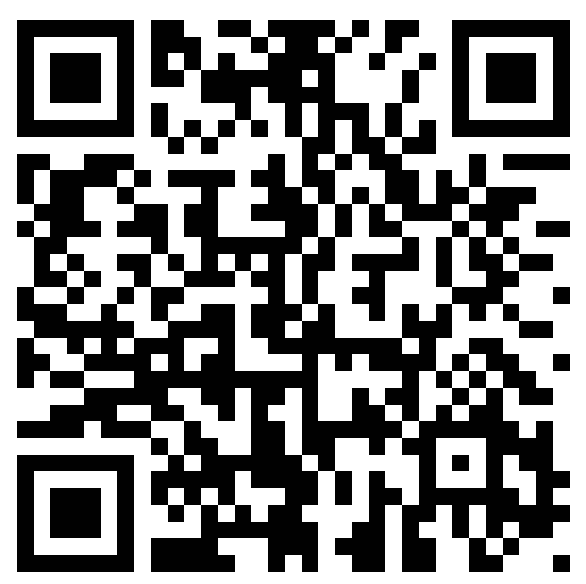

